\title{
ANTIMICROBIAL AND WATER REPELLENCY PERFORMANCE OF POLYPROPYLENE OUTDOOR FABRICS SUBJECTED TO SEQUENTIAL FINISHING PROCESSES
}

\author{
Erhan Kenan ÇEVEN* \\ Gizem KARAKAN GÜNAYDIN**i] \\ Dilek TOPRAKKAYA KUT*[C
}

Received: 08.07.2021; revised: 01.09.2021; accepted: 19.10.2021

\begin{abstract}
Polypropylene fabrics are one of the most preferred products for outdoor textiles. With the risks posed by the pandemic in the last year, outdoor textiles are expected to have some additional features such as antibacterial, antivirus, antimildew properties. Antimicrobial finishing and water repellency treatment may be applied consecutively on polypropylene fabrics. This research aims to investigate the effect of sequential finishing process by applying of different antimicrobial chemical ratio $(0,5$ and $10 \mathrm{~g} / \mathrm{l})$ and fluorocarbon-based water repelling substance $(0,30$ and $50 \mathrm{~g} / \mathrm{l})$ on antimicrobial efficiency and water repellency grades of outdoor fabrics. According to the results of statistical analyses, it was determined that antimicrobial efficiency against S. aureus and C. albicans was statistically influenced from process type at significance level of 0.05 , while antimicrobial efficiency against E.coli microorganism was not statistically influenced from process type. Antimicrobial activity of outdoor samples was more satisfying against $S$. aureus microorganism. Water repellency results generally improved as the applied amount of water repellent substance increased for the fabrics treated with the same amount of antimicrobial substance.
\end{abstract}

Keywords: Polypropylene, outdoor fabrics, antimicrobial, water repellency process

Ardışık Bitim İşlemi Görmüş Polipropilen Esaslı Dış Mekan Kumaşların Antimikrobiyel ve Su İtici Performanslarının İncelenmesi

Öz: D1ş mekân tekstilleri kapsamında en çok tercih edilen kumaşlardan bir tanesi polipropilen esaslı kumaşlardır. Son yıllarda pandeminin oluşturduğu risklerden dolayı dış mekân tekstillerinden antibakteriyel, antivirüs, küf önleyebilen bir takım ilave özellikler de beklenmektedir. Antimikrobiyel bitim işlemi ve su itici işlemler polipropilen kumaşlara ard arda uygulanabilmektedir. Bu çalışma farklı oranlarda antimikrobiyel $(0,5,10 \mathrm{gr} / \mathrm{lt})$ ve florokarbon esaslı su itici $(0,30$ ve $50 \mathrm{gr} / \mathrm{lt})$ kimyasalların ard arda uygulanmasıyla elde edilen dış mekân kumaşların antimikrobiyal etkinlik ve su itici seviyelerinin araştırılmasını hedeflemektedir. İstatiksel sonuçlara göre; S. aureus ve C. albicans mikroorganizmalarına karşı antibakteriyel etkinlik, proses türünden 0,05 anlamlılık seviyesinde etkilenmektedir. Polipropilen esaslı dış mekân kumaşları genel olarak S. aureus mikroorganizmasına karşı daha etkili bulunmuştur. Aynı miktar antimikrobiyal madde ile işlem gören kumaşlarda, uygulanan su itici madde miktarı arttıkça, su iticilik seviyeleri genel olarak iyileşmiştir.

Anahtar Kelimeler: Polipropilen, dış mekân tekstilleri, antimikrobiyal, su itici işlem

\footnotetext{
*Uludağ University, Faculty of Engineering, Department of Textile Engineering, 16120, Görükle, Bursa

***amukkale University, Buldan Vocational School, Fashion\&Design Programme, 20400, Buldan,Denizli Gizem KARAKAN GÜNAYDIN (ggunaydin@ pau.edu.tr)
} 


\section{INTRODUCTION}

Polypropylene fibre is one of the lightest synthetic fibres in existence, and it has high resistance to most acids and alkalis. Polypropylene (PP) fibres belong to the youngest generation of large scale produced chemical fibres. The development of PP fibres is commonly preferred owing to sufficient amount of basic raw material, low price, easy fibre forming as well as to their physic mechanical properties which provide the wide application in fields of home textiles, technical textiles and clothing. The main categories of PP fibres, fibrous and related materials are the following: monofilaments, multifilament, staple fibres, nonwoven textiles (spunbonds, melt blowns), tapes, split films, and others. Application of fibres, fibrous and polypropylene based textile materials can be sorted as carpets, underlays, rugs, hygiene textile products, tapes, ropes, clothing (home, sport, children's protective), geotextiles and agro textiles, wraps and big bags, technical textiles (filter and separation materials for the car industry, for composites manufacturing, for environmental-ECO textiles), textiles for medicine and others (Jambrich and Hodul, 1999; https://rilonfibers.com/blog/polypropylene-fiber; https://sewport.com/fabricsdirectory/polypropylene-fabric ). Polypropylene is a thermoplastic polymer which, because of its intrinsic properties (it does not absorb water, it has low density, low thermal conductivity, good resistance to different chemicals, it doesn't irritate skin etc.), is entering new markets at the expense of other polymers.

Some researchers have focused on antibacterial improvement of polypropylene fabrics. Huang et al. utilized quaternary ammonium salts on the surfaces of PP and obtained about a five log reduction of Escherichia coli using a dynamic shake flask test. Chitosan was applied on polypropylene nonwoven fabrics for providing antifungal and antibacterial functionalities in another study (Huang et al., 2007; Abdou et al, 2008). Cerkez et al. studied immobilization of anionic and cationic N-Halamine polyelectrolytes onto melt-blown polypropylene fabrics. It was found that the coatings had biocidal efficacy revealing about six log reductions of bacteria within two minutes of contact time (Çerkez et al., 2013). Badrossamay and Sun investigated the addition of several cyclic and acylic N-Halamines to the polypropylene during the extrusion process. The researchers concluded that very effective biocidal results were obtained where there were six log reductions of gram-positive and gram-negative bacteria within the contact time of 30-60 minutes (Badrossamay and Sun, 2008).

Apart from the antibacterial improvement of polypropylene, some investigations related to woven, knitted, and composite polypropylene textile products are mentioned below. Nielsen and Endrusick designed new knitting garments made of polypropylene fibre. Underwear garments manufactured from $100 \%$ polypropylene fibres in five different knit structures (1-by-1 rib, fleece, fishnet, interlock, double-layer rib) was evaluated in terms of thermal comfort properties. The differences in knit structure of the underwear provided significant differences in skin temperature, local and average skin wittedness, non-evaporated and evaporated sweat during the exercise test (Nielsen and Endrusick, 1990). In a study related to evaluation of the moisture management of the plated knitted fabrics; Polypropylene yarn (PP9 was used in the inner layer of the fabric where modified Micro-Pore Ring Spun Viscose yarn (MPRSVY) was used as the outer layer. It was concluded in the study that fabrics plated with PP inner layer required long time to be wet due to the hydrophobic nature of the polypropylene fibre and the sweat was found to be transferred through the fabric mainly by capillary forces. The sweat was directly transferred to the outer layer 
of the fabric and absorbed by the MPRSVY yarn which is very hydrophilic due to its micro-pores (Chandrasekaran et al., 2018).

Some research related to PP based composites were evaluated in terms of some physical properties such as tensile strength, flexural performance, water absorption...etc. Joseph et al. investigated the sisal fibre reinforced PP composites by melt mixing and solution-mixing methods. The tensile properties for PP, high temperature (HT) and low temperature (LT) specimens were compared. It was observed that the incorporation of sisal fibres increased young's modulus by about $150 \%$, and the tensile strength was increased by about $10 \%$ (Joseph et al., 1999). In another study related to composite polypropylene structures where the polypropylene films were combined with the discarded denim fabrics; The composites with different fibre weight fractions were designed and fabricated. The tensile, impact, and flame-retardant properties of the composites were investigated, and their morphology was observed by scanning electron microscopy. Discarded denim fabric/PP composites indicated good mechanical and flame retardant properties which showed that such product may substitute the traditional composites in automotive interior, packing materials and engineering materials (Wei et al., 2015). Woven polypropylene fabrics were applied to atmospheric pressure plasma and samples were evaluated in terms of mechanical behaviour, air permeability, water vapour permeability and thermal characteristics in research related to polypropylene fabrics. Tensile and friction coefficient measurements were also conducted. It was concluded in the study that polypropylene fabrics were influenced from atmospheric pressure treatment where the changes were believed to be closely related to the inter-fibre and inter-yarn frictional force (Yaman et al., 2010). In Abdou et al.' study; Nonwoven polypropylene and cotton fabrics were pre-treated with plasma followed by flash evaporation and radiation crosslinking acrylate polymer coating. Afterwards the samples were treated to chitosan solutions where chitosan was extracted from red shrimp. Antifungal activities of the modified membranes were examined. The effect was observed by the diameter of the inhibition zones. The obtained results revealed that the untreated PP fabrics had no inhibitory effect at all against all the tested fungal species. Fabrics treated with plasma then with chitosan revealed antifungal efficacy against all tested fungal species (Abdou et al., 2008). Studies on usage of staple polypropylene fibres in carpets, blankets, jersey fabrics, hand knitting yarns, furnishing fabrics, filter cloths have been going on. For example, blankets made of polypropylene staple fibre with low density have higher thicknesses compared to those with made of wool yarn at same count. Polypropylene carpets were emphasized to be having higher resilience and resistance to wear than a wool carpet. Wool carpet was completely worn through at 15, 000 treads while 50/50 polypropylene /wool blend was worn through at 60,000 treads. No sign of wear was observed for 100\% Polypropylene carpets even after 70,000 treads (Millard and West, 1962).

Polypropylene outdoor fabrics have been frequently preferred by the consumers due to its high resistance to chemicals, mild, moisture... etc. Those fabrics may contain important properties for outdoor use such as chloride, seawater fastness, light and weather resistance. The features of these fabrics are still being tried to be improved. It is expected to provide water repellent, unfading, mould resistant, stain proof fabric structures for outdoor fabrics (https://www.vipenvironment.com/outdoor-furniture-fabrics ).

The growth of microbes on textiles during usage and storage negatively affects the consumer as well as the textile itself. Natural and synthetic fibres vary in their reactions to microbial growth. 
Natural fibres are more prone to be attacked by the microbial due to their high-water retention. Enzymes of the microbial may easily hydrolyse the polymer linkages of the fibres such as cotton, wool, jute and flax. However, growth rate of microbes is slower on synthetic fibres when compared to natural fibres due to low water retention. Synthetic fibres become susceptible to microbial degradation when the additives such as polyethylene and polysiloxane emulsions are used as the finishing agents. Antimicrobial active agents may be incorporated into polymer extrusion or may be blended into the fibers during their formation. Antimicrobial finishing may be also applied on natural as well as on synthetic fibers with conventional exhaust and pad-drycure processes. Generally, antimicrobial finishes may be biocidal or biostatic. Biocides include agents that kill bacteria and fungi while biostats inhibit the microorganisms' growth (Simoncic and Tomsic, 2010; Arik, 2021).

The complexity of the conditions during use requires the multicriterial design of fabric structure and its testing to ensure a high number of functional characteristics such as tensile strength, abrasion resistance, resistance to light, antibacterial, chemical resistance and more. Antimicrobial processes may be combined with other additional features regarding to the markets' needs such as antimicrobial plus stain resistant plus UV protection or antimicrobial plus water repellency. For instance, considering the outdoor textiles, they may be used by many people in the public and should prevent antimicrobial effects. However at the same time, in outdoor textile ; protection against environmental factor is the initial function. In a wet environment, the basic requirement for is outdoor textile is to keep them dry with water repellency process. (Bagherzadeh et al., 2007). Water repellent textiles made of polypropylene have become more and more common in products for outdoor textiles such as tents, backpacks, hiking gear, insect repellent curtains..etc (Williams, 2017). Yüksel and Korkmaz declared in their study that high water resistance performance is expected from heavy duty outdoor fabrics such as tents, canopy and sleeping bag (Yüksel and Korkmaz, 2019). Hence beside with antimicrobial features, water repellency should be considered as a desired feature for outdoor textiles. Fluorocarbon polymers are good alternatives when oil repellency is desired along with water repellency. Fluorocarbon products are mostly padded, dried, and cured. Heat treatment provides an orientation of the perfluoro side chains to almost crystalline forms (Schindler and Hauser, 2004). By appropriate surface treatments, antimicrobial and water repellent features can be gained on those fabrics too. This study includes the influence of sequential application of antimicrobial and water repellency processes with varying ratios of antifungal and water repellent substance on antimicrobial and water repellency properties of outdoor fabrics.

\section{Material and Method}

Plain fabrics for outdoor use were produced on Dornier weaving machine by using the warp and weft yarns of 700/350 denier/filament air textured polypropylene yarns at $12 \mathrm{ends} / \mathrm{cm}$ and 12 picks $/ \mathrm{cm}$. Polypropylene outdoor fabrics were subjected to finishing processes of antimicrobial and water repellency processes consecutively. Microban ${ }^{\circledR}$ ZO6 R30700-480-EU (by Tanatex) Zinc Pyrithione based chemical agent was utilized as the antifungal and antibacterial substance with the ratios of 0,5 and $10 \mathrm{~g} / \mathrm{l}$. Zinc pyrithione (ZnPT) reveals efficacy and fast results toward a large range of microorganisms, such as Candida albicans, Escherichia coli, Pseudomonas aeruginosa, Salmonella choleraesuis and Staphylococcus aureus. An effective biocide should be able to move to the polymer surface, where it can prevent susceptible surface-colonizing cells, 
and hence delay biofilm accumulation. The biocide action of $\mathrm{ZnPT}$ relies on the inhibition of membrane transport and flow pumps of microorganisms preventing the accumulation of toxic substances inside the cells (Pittol et al., 2017).

For the water repellency treatment, Rucostar EEE6 (by Rudolf Duraner) C6-fluorocarbon resin with hyperbranched polymers in a hydrocarbon matrix based water repelling substance was used with the ratios of 0 (non-agent), $30 \mathrm{~g} / \mathrm{l}$ and $50 \mathrm{~g} / \mathrm{l}$. Process codes are presented in Table 1 with the ratio (\%) of applied finishing substance.

The outdoor fabrics were firstly impregnated for antimicrobial process with the wet pick up of $90 \%$ through ELTEKSMAK impregnating machine, dried at $130{ }^{\circ} \mathrm{C}$ for 45 seconds and cured at $135^{\circ} \mathrm{C}$ for 1.5 minute in Brückner Stenter .Pad-dry-cure method, is widely used for production of the functional textile products. Afterwards the same samples were exposed to water repellency finishing with the wet pick up of $75 \%$, dried at $140{ }^{\circ} \mathrm{C}$ for 1 minute and cured at $145^{\circ} \mathrm{C}$ for 2 minutes in Brückner Stenter. The experimental design for the fabrics is revealed in table 2. For example, $10-50$ coded treatment process refers to the antimicrobial process of $10 \mathrm{~g} / \mathrm{l}$ with the sequential finishing processes of water repellency where $50 \mathrm{~g} / \mathrm{l}$ chemical compound was applied.

Tablo 1. Fabric structure and experimental design

\begin{tabular}{|c|c|c|c|c|}
\hline Fabric code & $\begin{array}{c}\text { Warp yarn density } \\
\text { (thread/cm) }\end{array}$ & $\begin{array}{c}\text { Weft yarn density } \\
\text { (thread/cm) }\end{array}$ & $\begin{array}{c}\text { Fabric weight } \\
\qquad\left(\mathrm{g} / \mathrm{m}^{2}\right)\end{array}$ & Applied treatment code \\
\hline F1 & \multirow[t]{9}{*}{ 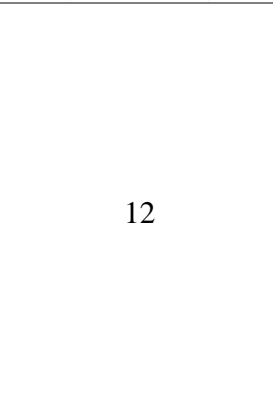 } & \multirow{9}{*}{12} & 203 & $0-0$ \\
\hline F2 & & & 217 & $0-30$ \\
\hline F3 & & & 223 & $0-50$ \\
\hline F4 & & & 225 & $5-0$ \\
\hline F5 & & & 226 & $5-30$ \\
\hline F6 & & & 219 & $5-50$ \\
\hline F7 & & & 207 & $10-0$ \\
\hline F8 & & & 218 & $10-30$ \\
\hline F9 & & & 228 & $10-50$ \\
\hline
\end{tabular}

Tablo 2. Process codes

\begin{tabular}{|c|c|c|}
\hline $\begin{array}{c}\text { Fabric } \\
\text { codes }\end{array}$ & antibacterial substance $(\mathrm{g} / \mathrm{l})$ & $\begin{array}{c}\text { Water } \\
\text { Repellent Ratio }(\mathrm{g} / \mathrm{l}) \\
\end{array}$ \\
\hline F1 & \multirow{3}{*}{0} & 0 \\
\hline $\mathrm{F} 2$ & & 30 \\
\hline $\mathrm{F} 3$ & & 50 \\
\hline $\mathrm{F} 4$ & \multirow{3}{*}{5} & 0 \\
\hline F5 & & 30 \\
\hline F6 & & 50 \\
\hline $\mathrm{F} 7$ & \multirow{3}{*}{10} & 0 \\
\hline F8 & & 30 \\
\hline F9 & & 50 \\
\hline
\end{tabular}

\subsection{Antimicrobial Test}

Prior to all tests, all fabrics were conditioned for $24 \mathrm{~h}$ in standard atmospheric conditions (at the temperature of $20 \pm 2 \mathrm{C}^{\circ}$ and relative humidity of $65 \pm 2 \%$ ). The outdoor fabrics produced within this research were evaluated for their antimicrobial efficiency according to test standards 
Çeven K. E., et al: Antmic. Wtr. Repellncy. Perfrm. Polyprop. Outdr. Fbrc. Subjec. Sequent. Fnsh. Proces.

of ASTM 2149 (Standard Test Method for Determining the Antimicrobial Activity of Immobilized Antimicrobial Agents Under Dynamic Contact Conditions) and AATCC 147 (Antibacterial Activity Assessment on Textile Materials). Gram-positive bacteria Staphylococcus aureus $\left(\mathrm{ATCC}^{\circledR} 6538^{\mathrm{TM}}\right.$ ) and gram-negative Escherichia coli $\left(\mathrm{ATCC}^{\circledR} 25922^{\mathrm{TM}}\right.$ ) and a strain of yeast as Candida albicans $\left(\mathrm{ATCC}^{\circledR} 10231^{\mathrm{TM}}\right.$ ) were used as the test micro-organisms.

\subsubsection{ASTM 2149 (Standard Test Method for Determining the Antimicrobial Activity of Immobilized Antimicrobial Agents Under Dynamic Contact Conditions)}

Considering the principle of ASTM 2149-13a; After preparation and incubation of test inoculums, diluted solutions of microorganisms were obtained where consecutive dilutions were repeated by taking $1 \mathrm{ml}$ of previous solution and mixing with $9 \mathrm{ml}$ of sterile physiological water (SPW). As the bacterial concentration was diluted to $1.5 \times 10^{5} \mathrm{CFU} / \mathrm{ml}$, sterilized textile samples $(3 \times 3 \mathrm{~cm})$ were added to each flask and shaken vigorously for 1 hour at $37 \mathrm{C}^{\circ}$ in shaking incubator. Diluted solutions of $1 \mathrm{ml}$ are taken from these flasks and then they were poured onto the petri dishes. Then nutrition agar PCA (Plate Count Agar) for S. aureus and E. coli; PDA (Potato Dextrose Agar) for C. albicans was also added to those petri dishes. Finally, incubation of petri dishes was conducted at $37 \mathrm{C}^{\circ}$ in conventional incubator for $S$. aureus and E. coli; at $25 \mathrm{C}^{\circ}$ in conventional incubator for C. albicans. Afterwards, viable colonies of bacteria (S. aureus and $E$. coli) were determined after 24 hours, viable colonies of yeast ( $C$. albicans) were determined after 72 hours. All stages were followed for the test flasks being shaken for 24 hours at $37 \mathrm{C}^{\circ}$ in shaking incubator (ASTM E2149-13a, 2001).

The reduction in number of microorganisms was calculated with following equation (1):

$$
\text { Reduction rate }(\%)=[(B-A) / B] \times 100
$$

Where $A$ is number of microorganisms recovered from inoculated test flasks incubated over the desired shaking period (1h). $B$ is the number of microorganisms recovered from reference test flasks immediately after 1 hour shaking. Within the study, the untreated fabric samples were used for the reference test flasks.

\subsubsection{AATCC 147 parallel streak method}

Additionally, antimicrobial activity was evaluated according to AATCC 147-2004 parallel streak test method against $E$. Coli and $S$. Aureus microorganisms. The qualitative determination of antimicrobial activity against E.Coli (gram negative), S. Aureus (gram positive) was made based on the protocol of the AATCC Test Method 147-2004. In order to perform the AATCC 147 method, an inoculum was prepared as follows: $1.0 \pm 0.1 \mathrm{ml}$ of a $24 \mathrm{~h}$ culture in nutrient broth (NB) was transferred into $9.0 \pm 0.1 \mathrm{ml}$ of sterile distilled water. With an inoculating loop, five streaks of the diluted inoculum were made over a standard Petri dish with nutrient agar (NA), without refilling the loop. The textile samples of $5 \mathrm{~cm} \times 2 \mathrm{~cm}$ were placed over the streaks, ensuring intimate contact with the agar surface. The petri dishes were incubated for $24 \mathrm{~h}$ at $37 \pm 2^{\circ} \mathrm{C}$ (AATCC 147, 2004). Additionally, AATCC 147-30 parallel streak test method against Candida albicans ATCC 10231 was also conducted with the same method. 


\subsection{Water Repellency Test}

The water repellency tests were performed according to AATCC 22:2010 Spray Test. Water sprayed against the taut surface of a test specimen $(18 \mathrm{~cm} \times 18 \mathrm{~cm})$ under controlled conditions produces a wetted pattern of which size depends on the repellence of the fabric. Evaluation is accomplished by comparing the wetted pattern with pictures on a standard chart. The rating marks regarding to the specimens' surfaces are indicated below (AATCC Test Method 22, 2010).

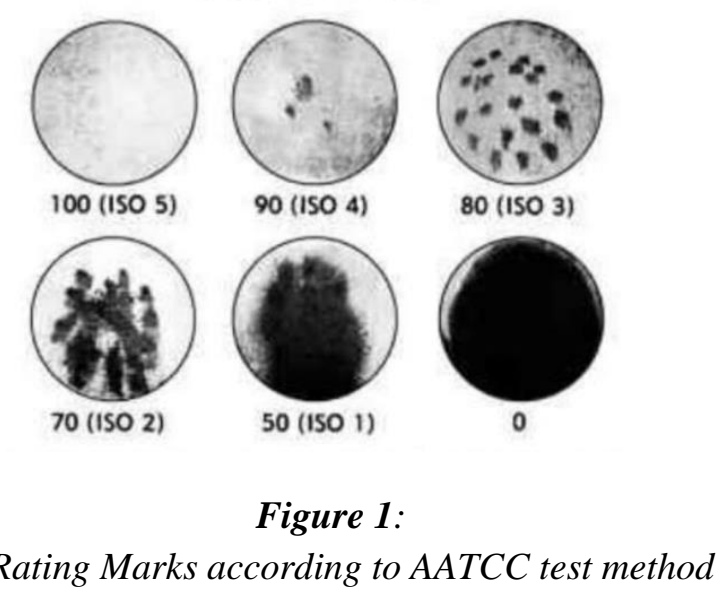

\subsection{Statistical Analyses}

Randomized one-direction ANOVA was performed to interpret the statistical significance of treatment type (including antibacterial and water repellent finishing) on outdoor fabrics' antibacterial efficiency in terms of microorganisms' reduction (\%) obtained from the shake flask method. SNK (Student Newman Keul) was also benefited from to compare the means of microorganisms' reduction (\%) results.

\section{Results and Discussion}

\subsection{Antimicrobial Properties}

Hydrophobicity and electrical properties of the surface are important for microorganisms to adhere to the surface. Polypropylene is a partially crystalline fibre. In general, polypropylene fibre has excellent chemical resistance to acids and alkalis, resistant to bacteria and microorganisms. The chemical substance used in obtaining antimicrobial effect is in the structure of zinc pyrithione. Zinc pyrithione is a coordination complex of zinc. The pyrithione ligands, which are formally monoanions, are chelated to $\mathrm{Zn} 2+$ via oxygen and sulfur centers. It has fungistatic and bacteriostatic properties. It inhibits the division of fungal cells and bacterial cell division. Due to its high activity in fungi and gram-positive and gram-negative bacteria, zinc pyrithione has been broadly used in various fields (Park et al., 2020). The effects obtained after the antimicrobial treatment applied to polypropylene outdoor fabrics are given in figure 2 . 


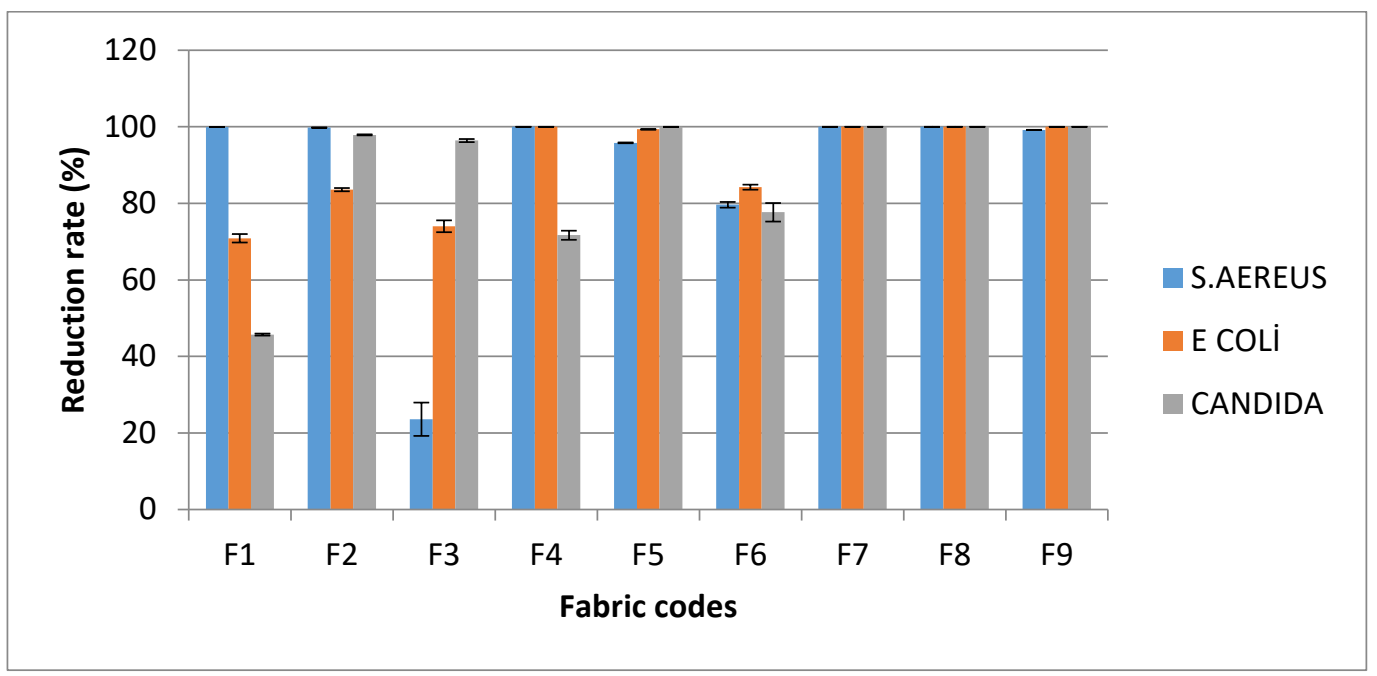

Figure 2:

Antimicrobial activity of outdoor fabrics against S.Aureus, E coli and Candida microorganisms (ASTM 2149 method)

The reduction in number of microorganism (\%) calculated according to the formula (equation 1) was utilized as a determinative for the antimicrobial activity of the samples (figure 2). Considering the antimicrobial activity against S.aureus, the polypropylene outdoor fabrics generally exhibited satisfying results. Even the fabric groups including F1, F2 and F3 coded fabrics which are not exposed to any antibacterial process revealed antimicrobial activity owing to polypropylene fibre's inherited antimicrobial and hydrophobic structure (Karacan and Wang, 1997). It was declared in Cook's study that Polypropylene is a paraffinic hydrocarbon, and it does not absorb water. Polypropylene fibre does not support the growth of mildew or fungi (Cook, 1984).

However, F3 coded fabric treated with 0-50 process code which includes only water repellency with the ratio of $50 \mathrm{~g} / \mathrm{l}$ water repellent substance revealed the lowest reduction rate (\%) against $S$. Aureus. When the antibacterial activity against $E$. Coli is considered, F4, F7, F8 and F9 coded fabrics revealed higher antibacterial resistance against $E$. Coli compared to other outdoor samples. On the other hand, F1 coded fabric indicated the lowest reduction rate (\%) against $E$. Coli. As figure 2 is observed, it can be understood that antimicrobial activity of the samples was less satisfying against $E$. coli reduction (\%) according to the bar graph. This may be attributed to E.coli bacteria being more resistant compared to S. Aureus (Rahman et al., 2021). When the antifungal activity against $C$. albicans is evaluated, most satisfying antifungal activity was observed among F5, F7, F8 and F9 coded fabrics which were treated with 5 and $10 \mathrm{~g} / \mathrm{l}$ antimicrobial substance, respectively. On the other hand, a fluctuating trend of antifungal activity was observed among F1, F2, F3, F4, F6 coded fabrics. As it is also observed in figure 2, F1 coded fabrics indicated the minimum reduction rate (\%) against Candida. When the result is evaluated, this may be due to $\mathrm{F} 1$ fabrics not exposing to any antimicrobial or water repellency process. Water repellence functionality may also increase the antimicrobial efficiency for polypropylene fabrics making them much more hydrophobic and making them more protective also against the microbial attacks. Similarly in Bagherzadeh' study, polyester knitted spacer fabrics were finished with water repellent and antimicrobial agents. The authors declared in the study that increasing 
of concentration of water repellent agents leads to lower amount of passed and absorbed water as well as preventing growing of microorganisms (Bagherzadeh et al., 2007). F7, F8 and F9 fabrics seem to be having the best satisfying results for antimicrobial activity against all three microorganisms. This is due to maximum application amount of antimicrobial substance $(\mathrm{g} / \mathrm{l})$ on these samples.

Additionally, in order to evaluate the influence of process type on fabric samples' antimicrobial activity against gram positive (S. aureus), gram negative (E.coli) and candida, completely randomized one-factor analysis of variance (ANOVA) was conducted where process type was determined as the variable factor. The results were compared in terms of reduction percent $(\%)$ of the microorganisms determined from shake flask method mentioned in material method part. According to the completely randomized one-factor analysis of variance (ANOVA) conducted for $S$. aureus, it was observed that process type had a significant effect (5\% significant level) on antibacterial efficiency of the samples in terms of S. aureus reduction (\%). According to SNK results of antibacterial activity against $S$. aureus, it was observed that the fabrics treated with different process type revealed different reduction (\%) of S.aereus, at significance level of 0.05. Considering the reduction (\%) of S.aereus; the lowest reduction (\%) of S.aereus microorganism was observed among the samples treated with 50-0 process while the highest reduction (\%) was observed among the samples treated with 5-0 and 10-30 processes.

Considering the antibacterial activity against gram negative (E. coli ), there was not a significant influence of process type on the antibacterial activity of the samples against E.coli $(\%)$ at significance level of 0.05 . When it comes to the antifungal activity against $C$. albicans; It is observed that process type had a significant effect on the antimicrobial activity of the fabric samples.

Considering the SNK results of the candida reduction (\%); the most satisfying antifungal activities were obtained from the outdoor samples treated with 10-0, 10-30, 10-50 coded processes while the lowest reduction rates (\%) were observed among the untreated samples which does not include any antibacterial or water repellency treatment as expected. As a general result it may be also added that especially among the fabrics treated with $5 \mathrm{~g} / \mathrm{l}$ antibacterial substance, a reduction of antimicrobial activity against S.Aereus and Candida was observed as the applied water repellent ratio increased from $30 \mathrm{~g} / \mathrm{l}$ to $50 \mathrm{~g} / \mathrm{l}$. This may be anticipated from those results that water repellent chemical substance may have a reducing effect of antibacterial process when they are applied in the sequential finishing processes A similar situation was observed in our previous study where the water repellent chemical substance reduced the flame retardancy effect for polyester upholstery fabrics (Günaydın et al., 2021) 
Table 3. ANOVA results for antimicrobial activity

\begin{tabular}{|l|c|c|c|c|c|c|c|c|c|c|}
\hline \multicolumn{2}{|c|}{} & \multicolumn{5}{|c|}{ S.aereus } & \multicolumn{3}{c|}{ E.coli } & \multicolumn{3}{c|}{ Candida } \\
\cline { 2 - 10 } Process type & df & F & $\begin{array}{c}\text { Sig } \\
\text { (p) }\end{array}$ & df & F & $\begin{array}{c}\text { Sig } \\
\text { (p) }\end{array}$ & df & F & $\begin{array}{c}\text { Sig } \\
(p)\end{array}$ \\
\hline Main Effect & $\begin{array}{c}\text { Process } \\
\text { Type (T) }\end{array}$ & 8 & 294.140 & $0.00 *$ & 8 & 1.73 & 0.17 & 8 & 9.06 & $0.00 *$ \\
\hline
\end{tabular}

Table 4. SNK results for reduction (\%) of S.aereus and Candida microorganism

\begin{tabular}{|c|c|c|c|c|}
\hline \multicolumn{2}{|c|}{ Parameter } & Fabric code & S.aereus & Candida \\
\hline \multirow{7}{*}{} & & & & \\
\cline { 2 - 5 } & $0-0$ & F1 & $99.91 \mathrm{c}$ & $45.70 \mathrm{a}$ \\
\cline { 2 - 5 } & $0-30$ & F2 & $99.77 \mathrm{c}$ & $97.89 \mathrm{~d}$ \\
\cline { 2 - 5 } & $0-50$ & F3 & $23.58 \mathrm{a}$ & $96.40 \mathrm{~d}$ \\
\cline { 2 - 5 } & $5-0$ & F4 & $99.99 \mathrm{c}$ & $71.66 \mathrm{~b}$ \\
\cline { 2 - 5 } & $5-30$ & F5 & $95.80 \mathrm{c}$ & $99.99 \mathrm{~d}$ \\
\cline { 2 - 5 } & $5-50$ & F6 & $79.61 \mathrm{~b}$ & $77.65 \mathrm{c}$ \\
\cline { 2 - 5 } & $10-0$ & F7 & $99.98 \mathrm{c}$ & $99.99 \mathrm{~d}$ \\
\cline { 2 - 5 } & $10-30$ & F8 & $99.99 \mathrm{c}$ & $99.99 \mathrm{~d}$ \\
\cline { 2 - 5 } & $10-50$ & F9 & $99.17 \mathrm{c}$ & $99.99 \mathrm{~d}$ \\
\hline
\end{tabular}

Note. The different letters next to the counts indicate that they are significantly different from each other at a significance level of 0.05

The fabric samples were also evaluated regarding to their antimicrobial activity according to AATCC 147 parallel streak method against Escherichia Coli, Staphylococcus Aureus and Candida. Table 5 indicates the antimicrobial activity of fabric samples against Escherichia Coli , Staphylococcus Aureus and Candida microorganism. When F1 coded fabric is considered, there was not any inhibition zone against Staphylococcus Aureus and against E.coli with little growth of bacteria in the contact surface. However intensive growth of Candida was observed in the contact area. As F2 coded fabrics are considered, no inhibition zone against E. coli was observed with moderate level of growth in the contact surface. No inhibition zone was observed against Staphylococcus Aureus and Candida. Intensive growth of C.albicans was observed under the contact surface. For the F3 coded fabrics, no inhibition zone was observed against $E$. coli with little growth under the contact surface. Additionally, an inhibition zone against Staphylococcus Aureus with little growth was observed while there was no inhibition zone observed against Candida. F4 coded fabric provided a prominent inhibition zone against E.coli, Staphylococcus Aureus and Candida without any growth. The same situation was observed for the F5 coded fabric 
however there was little Candida growth under the contact surface. As F6 coded fabric is considered, an inhibition zone against E.coli, Staphylococcus Aureus and Candida was observed. There was no growth of Staphylococcus Aureus and Candida under the contact surface. F7, F8 and F9 coded fabrics provided prominent inhibition zones against E.coli, Staphylococcus Aureus and Candida without any growth. A remarkable antimicrobial activity underneath those three fabrics were observed. Some visual appearances of antimicrobial activity of the samples against three mentioned bacteria cultures were also displayed below in table 6 which were in accordance with table 5.

Table 5. Antibacterial assessment against bacterial cultures

\begin{tabular}{|c|c|c|c|c|c|c|}
\hline \multirow[b]{2}{*}{$\begin{array}{l}\text { Fabric } \\
\text { code }\end{array}$} & \multicolumn{2}{|c|}{ E.coli } & \multicolumn{2}{|c|}{ S.Aureus } & \multicolumn{2}{|c|}{ C.albicans } \\
\hline & $\begin{array}{c}\text { observed } \\
\text { inhibition } \\
\text { zone } \\
\end{array}$ & $\begin{array}{c}\text { growth } \\
\text { under the } \\
\text { contact surface }\end{array}$ & $\begin{array}{c}\text { observed } \\
\text { inhibition } \\
\text { zone } \\
\end{array}$ & $\begin{array}{c}\text { growth } \\
\text { under the contact } \\
\text { surface }\end{array}$ & $\begin{array}{c}\text { observed inhibition } \\
\text { zone }\end{array}$ & $\begin{array}{c}\text { growth } \\
\text { under the contact } \\
\text { surface }\end{array}$ \\
\hline $\mathrm{F} 1$ & $\begin{array}{c}\text { no inhibition } \\
\text { zone }\end{array}$ & little growth & $\begin{array}{c}\text { no inhibition } \\
\text { zone }\end{array}$ & little growth & no inhibition & intensive growth \\
\hline $\mathrm{F} 2$ & $\begin{array}{l}\text { no inhibition } \\
\text { zone }\end{array}$ & $\begin{array}{l}\text { moderate level } \\
\text { of growth }\end{array}$ & $\begin{array}{c}\text { no } \\
\text { inhibition } \\
\text { zone } \\
\end{array}$ & little growth & no inhibiton zone & little growth \\
\hline $\mathrm{F} 3$ & $\begin{array}{c}\text { no inhibition } \\
\text { zone }\end{array}$ & $\begin{array}{l}\text { moderate level } \\
\text { of growth }\end{array}$ & $\begin{array}{l}\text { inhibition } \\
\text { zone }\end{array}$ & little growth & no inhibition zone & moderate gowth \\
\hline $\mathrm{F} 4$ & $\begin{array}{l}\text { inhibition } \\
\text { zone }\end{array}$ & no growth & $\begin{array}{c}\text { inhibition } \\
\text { zone }\end{array}$ & no growth & inhibition zone & no growth \\
\hline F5 & $\begin{array}{l}\text { inhibition } \\
\text { zone }\end{array}$ & no growth & $\begin{array}{l}\text { inhibition } \\
\text { zone }\end{array}$ & no growth & inhibition zone & little growth \\
\hline F6 & $\begin{array}{l}\text { inhibition } \\
\text { zone }\end{array}$ & little growth & $\begin{array}{l}\text { inhibition } \\
\text { zone }\end{array}$ & no growth & inhibition zone & no growth \\
\hline F7 & $\begin{array}{l}\text { inhibition } \\
\text { zone }\end{array}$ & no growth & $\begin{array}{l}\text { inhibition } \\
\text { zone }\end{array}$ & no growth & inhibition zone & no growth \\
\hline F8 & $\begin{array}{l}\text { inhibition } \\
\text { zone }\end{array}$ & no growth & $\begin{array}{l}\text { inhibition } \\
\text { zone }\end{array}$ & no growth & inhibition zone & no growth \\
\hline F9 & $\begin{array}{l}\text { inhibition } \\
\text { zone }\end{array}$ & no growth & $\begin{array}{l}\text { inhibition } \\
\text { zone }\end{array}$ & no growth & inhibition zone & no growth \\
\hline
\end{tabular}


Çeven K. E., et al: Antmic. Wtr. Repellncy. Perfrm. Polyprop. Outdr. Fbrc. Subjec. Sequent. Fnsh. Proces.

Table 6. Antibacterial assessment of fabrics against S.Aureus, $E$ coli and Candida (AATCC 147 parallel streak method )
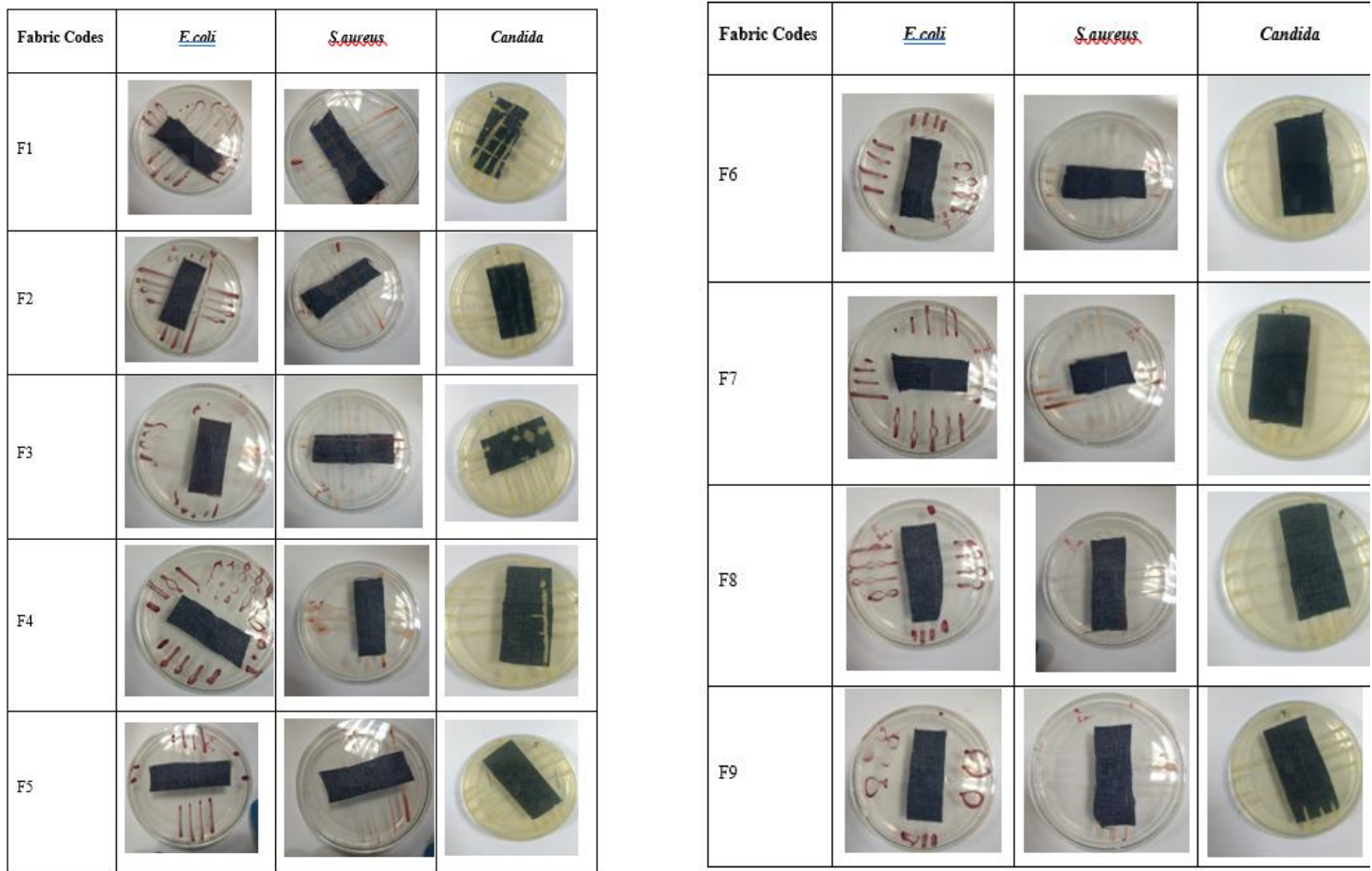

\section{Water Repellency}

According to spray test results (figure 3, table 7,8), the most satisfying test results in terms of water repellency were obtained from F5 coded fabrics which are exposed to 5-30 coded process. On the other hand, the worst water repellency grade was obtained from F1 coded untreated fabrics with water repellency grade of " 0 ". Water repellency grade of F3 and F4 coded fabrics were similar to each other. The samples' images obtained during the water repellency test are indicated below table 7 . 
Table 7. Fabric images after spray test

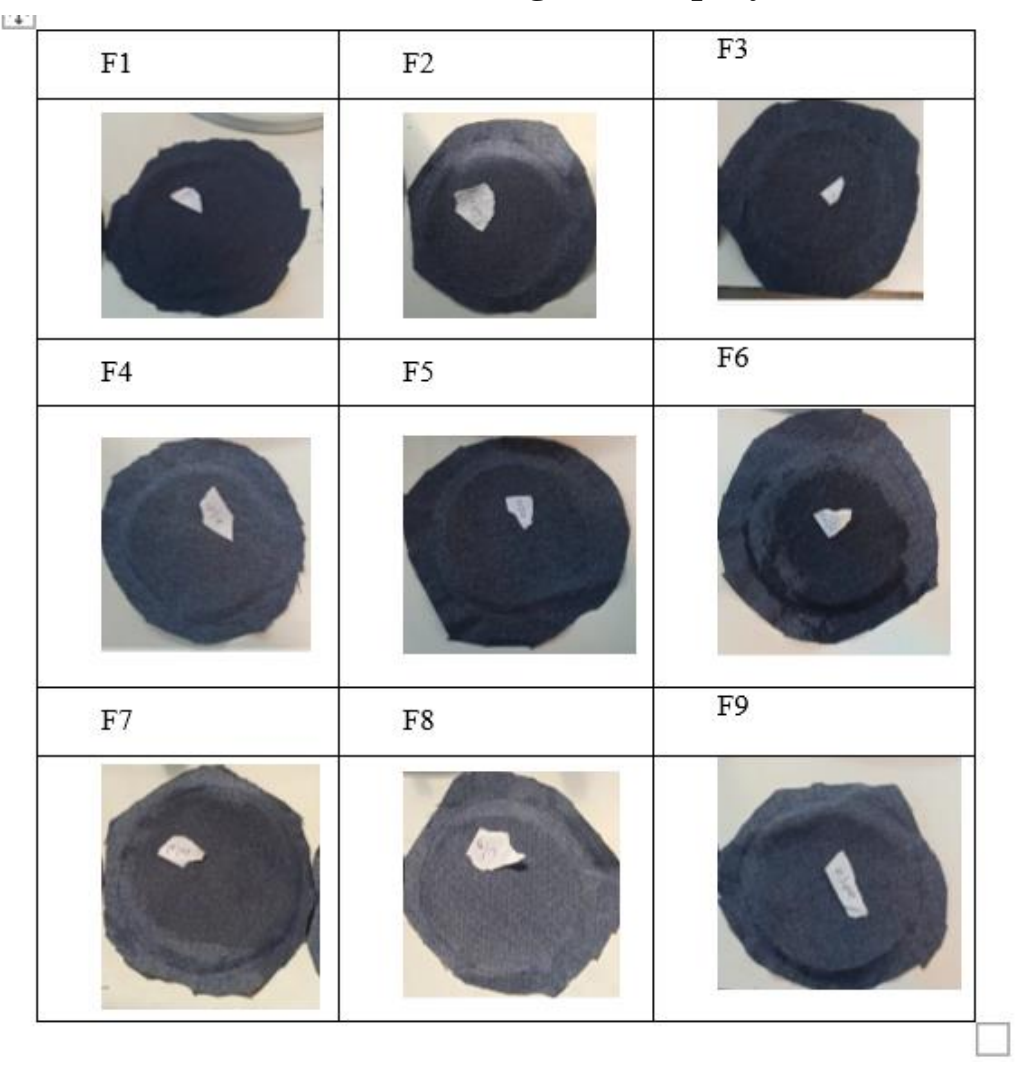

Table 8. Spray test results

\begin{tabular}{|c|c|}
\hline Fabric & water repellency grade \\
\hline F1 & 0 \\
\hline F2 & 80 \\
\hline F3 & 90 \\
\hline F4 & 90 \\
\hline F5 & 100 \\
\hline F6 & $50 / 70$ \\
\hline F7 & 50 \\
\hline F8 & $90 / 100$ \\
\hline F9 & $90 / 100$ \\
\hline
\end{tabular}




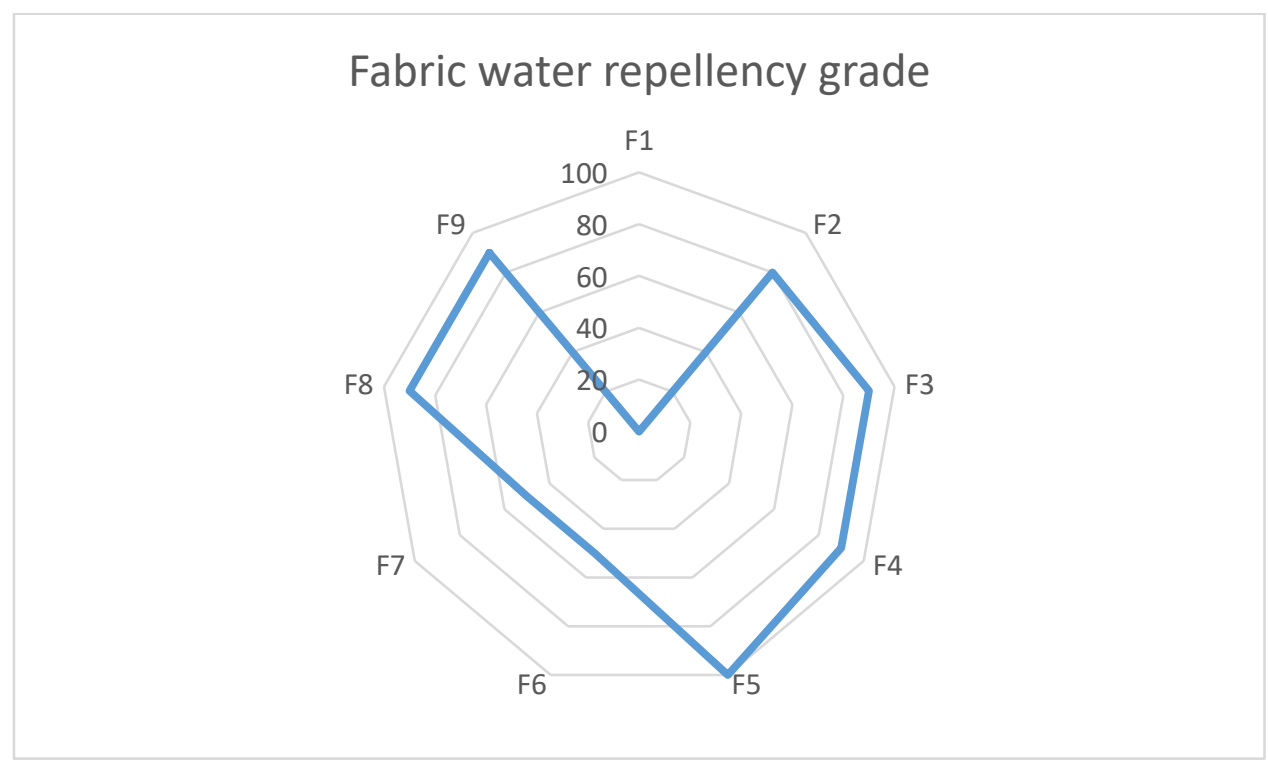

Figure 3:

Spray test results of fabrics

As a general result, when the fabrics treated with the same amount of antibacterial substance are compared, it is observed that water repellency grade improves as the amount of water repellent substance gradually increases from $0 \mathrm{~g} / \mathrm{l}$ to $50 \mathrm{~g} / \mathrm{l}$. However, the only case that does not fit this expression was found among the F6 coded fabrics for the samples treated with the same amount of antibacterial finishing ( $5 \mathrm{~g} / \mathrm{l}$ antibacterial substance). This may be explained with suppression of the water repellent substance's potential effect with the combination of antibacterial process with water repellency process.

\section{CONCLUSION}

Popularity of outdoor fabrics has been increasing rapidly as the comfort features come to the fore in the outdoor area. Those fabrics are required to have some special features such as antimicrobial, water repellency, mildew prevention since they are exposed to more external factors compared to indoor textiles. This study has been conducted to investigate the effect of process type on antibacterial and water repellency properties of the fabric samples. The antibacterial and the water repellency processes were performed consecutively in each process type. The results may be summarized as below:

*It was observed that process type had a significant effect (5\% significant level) on antibacterial efficiency of the samples in terms of $S$. aureus reduction (\%) according to one-factor analysis of variance (ANOVA) results. Considering the antibacterial activity against gram negative (E. coli), there was not a significant influence of process type on the antibacterial activity of the samples against E.coli (\%) at significance level of 0.05 . When it comes to the antifungal activity against C. Albicans; It was observed that process type had a significant effect on the antibacterial activity of the fabric samples.

* It may be also anticipated that the antimicrobial activity of the samples was more satisfying against the S. aureus (\%) according to the bar graph of microorganism reduction (\%). Additionally 
as a general result, fabric samples treated with only antimicrobial process generally revealed better results with higher reduction (\%) of S.aereus and Candida microorganism.

* Bar graphs and SNK results revealed that increase of water repellent ratio led to degradations in antimicrobial results especially after the ratio of $30 \mathrm{~g} / \mathrm{l}$ water repellent substance in the combined processes. This is due to different ionic charges of chemicals used in the consecutive processes.

*Test results of Parallel streak method revealed that inhibition zones were observed against all three microorganisms (S. aureus, E.coli , C. albicans) except F1,F2, F3 coded fabrics.

* Water repellency results generally improved as the amount of water repellent substance increased for the fabrics treated with the same amount of antibacterial substance.

Acknowledgement: We wish to express our special thanks to Bülent Aslan (production manager), Ece Tosunoglu, Serkan Ataman and all staff of Tosunoğlu Textile Company (Denizli, Turkey) for their technical support.

\section{CONFLICT OF INTEREST}

Author approve that to the best of their knowledge, there is not any conflict of interest or common interest with an institution/organization or a person that may affect the review process of the paper

\section{AUTHOR CONTRIBUTION}

Erhan Kenan Çeven, Gizem Karakan Günaydın, Dilek Toprakkaya Kut: determining the concept and design process of the research and research management; data collection and analysis; data analysis and interpretation of results.

\section{REFERENCES}

1. AATCC 147:2004, "Antimicrobial Activity Assessment of Textile Materials: Parallel Streak Method", 2004.

2. AATCC Test Method 22, "Water repellency, spray test", Research Triangle Park, NC: Author, 2010. Retrieved from https://www.aatcc.org/.

3. Abdou, E. S., Elkholy, S. S., Elsabee, M. Z., \& Mohamed, E. (2008). Improved antimicrobial activity of polypropylene and cotton nonwoven fabrics by surface treatment and modification with chitosan, Journal of Applied Polymer Science, 108(4), 2290-2296.

4. Arık, B. (2021). Common and nano-antimicrobial textile finishes. In Antimicrobial Textiles from Natural Resources (pp. 87-117). Woodhead Publishing.

5. ASTM E2149-13a, 'Standard Test Method for Determining the Antimicrobial Activity of Antimicrobial Agents Under Dynamic Contact Conditions', 2001.

6. Badrossamay, M. R., \& Sun, G. (2008). Acyclic halamine polypropylene polymer: Effect of monomer structure on grafting efficiency, stability and biocidal activities, Reactive and Functional Polymers, 68(12), 1636-1645. Doi: https://doi.org/10.1016/j.reactfunctpolym.2008.09.012 
Çeven K. E., et al: Antmic. Wtr. Repellncy. Perfrm. Polyprop. Outdr. Fbrc. Subjec. Sequent. Fnsh. Proces.

7. Bagherzadeh, R., Montazer, M., Latifi, M., Sheikhzadeh, M., \& Sattari, M. (2007). Evaluation of comfort properties of polyester knitted spacer fabrics finished with water repellent and antimicrobial agents, Fibers and Polymers, 8(4), 386-392.

8. Chandrasekaran, V., Senthilkumar, P., \& Sakthivel, J. C. (2018). Study on moisture management properties of micro-pore ring-spun viscose yarn-plated knitted fabrics. The Journal of the Textile Institute, 109(11), 1458-1464. Doi: 10.1080/00405000.2018.1423884.

9. Cook, J. G., 1984, Handbook of textile fibers, Volume 2. Man-Made Fibres. pp 750, Woodhead publishing,

10. Cerkez, I., Worley, S. D., Broughton, R. M., \& Huang, T. S. (2013). Antimicrobial surface coatings for polypropylene nonwoven fabrics, Reactive and Functional Polymers, 73(11), 1412-1419. Doi: https://doi.org/10.1016/j.reactfunctpolym.2013.07.016

11. Günaydın, G.K., Çeven, E. K., Gürarda, A., \& Akgün, M. (2021). A research on effect of surface treatment conditions on flammability and water repellency properties of drapery fabrics produced from micro polyester yarns. Journal of the Textile Institute, 112(2), 233242. Doi: $10.1080 / 00405000.2020 .1736425$.

12. https://rilonfibers.com/blog/polypropylene-fiber/, accessed, march 20, 2020.

13. https://sewport.com/fabrics-directory/polypropylene-fabric, accessed, march 20, 2020.

14. https://www.vip-environment.com/outdoor-furniture-fabrics, accessed, february 10, 2021.

15. Huang, J., Murata, H., Koepsel, R. R., Russell, A. J., \& Matyjaszewski, K. (2007). Antibacterial polypropylene via surface-initiated atom transfer radical $\begin{array}{lllll}\text { polymerization. } & \text { Biomacromolecules, } & 8 & \text { (5), 1396-1399. Doi: }\end{array}$ https://doi.org/10.1021/bm061236j

16. Jambrich, M., \& Hodul, P. (1999). Textile applications of polypropylene fibers. In Polypropylene (pp. 806-812). Springer, Dordrecht.

17. Joseph, PV., Kuruvilla, J. and Sabu T. (1999). Effect of processing variables on the mechanical properties of sisal fiber-reinforced polypropylene composites, Composites Science and Technology, 59(11), 1625-1640. Doi: https://doi.org/10.1016/S02663538(99)00024-X

18. Karacan, İ., \& Wang, I. C. (1997). İzotaktik Polipropilen Liflerinin Yapısal Çalışmaları ,Tekstil ve Mühendis, 11(56).

19. Millard, F., \& West, K. (1962). The Properties of Textile Fibers Made from Polypropylene. Journal of the Textile Institute Proceedings, 53(8), P465-P480.

20. Nielsen, R., \& Endrusick, T. L. (1990). Thermoregulatory responses to intermittent exercise are influenced by knit structure of underwear, European journal of applied physiology and occupational physiology, 60(1), 15-25.

21. Park, C. Y., Moon, S., Baek, S. H., Kim, M. W., Roh, J., Sung, J., \& Park, T. J. (2020). Development of detection methods for zinc pyrithione in polypropylene via simple extraction methods for quality control, BioChip Journal, 14(2), 211-217. Doi: 10.1007/s13206-0204210-7

22. Pittol, M., Tomacheski, D., Simões, D. N., Ribeiro, V. F., \& Santana, R. M. C. (2017). Antimicrobial performance of thermoplastic elastomers containing zinc pyrithione and silver nanoparticles. Materials Research, 20, 1266-1273. Doi: http://dx.doi.org/10.1590/19805373-MR-2017-0137. 
23. Rahman, M. S., Mondal, M. I. H., Hasan, M. S., Alom, J., Ahmed, M. B., \& Ahmed, F. (2021). Microorganisms, infection, and the role of medical textiles. In Antimicrobial Textiles from Natural Resources (pp. 45-85). Woodhead Publishing.

24. Schindler, W. D., \& Hauser, P. J. (2004). Chemical finishing of textiles. Elsevier.

25. Simoncic, B., \& Tomsic, B. (2010). Structures of novel antimicrobial agents for textiles-a review, Textile Research Journal, 80(16), 1721-1737. Doi: 10.1177/0040517510363193

26. Wei, B., Xu, F., Azhar, S. W., Li, W., Lou, L., Liu, W., \& Qiu, Y. (2015). Fabrication and property of discarded denim fabric/polypropylene composites, Journal of Industrial Textiles, 44(5), 798-812. Doi: https://doi.org/10.1177\%2F1528083714550055.

27. Williams, J. T. (Ed.). (2017). Waterproof and water repellent textiles and clothing. Woodhead Publishing, Textile Institute, United Kingdom.

28. Yaman, N., Özdoğan, E., \& Seventekin, N. (2010). Evaluation of some of the physical properties of atmospheric plasma treated polypropylene fabric, The Journal of The Textile Institute, 101(8), 746-752. Doi: 10.1080/00405000902843433.

29. Yüksel, Y. E., \& Korkmaz, Y. (2019). Investigation of sewing and water repellent performance of outdoor clothing, International Journal of Clothing Science and Technology, 31(5), 693-704. Doi: 10.1108/IJCST-09-2018-0119. 
